\title{
Control Equipment for Pile Test According to American and Kazakhstan Standards
}

\author{
Assel S. Tulebekova ${ }^{1}$ \\ ${ }^{1}$ L N Gumilyov Eurasian National University, Astana, Kazakhstan \\ Correspondence: Assel S. Tulebekova, L N Gumilyov Eurasian National University, Astana, Kazakhstan. Tel: \\ 7-701-648-1866. E-mail: krasavka5@mail.ru
}

Received: December 12, 2015

Accepted: November 22, $2014 \quad$ Online Published: May 30, 2015

doi:10.5539/mas.v9n6p192

URL: http://dx.doi.org/10.5539/mas.v9n6p192

\begin{abstract}
Paper presented methodic of testing pile by ASTM D1143/D1143M-07 (USA) standard and GOST 5686-94 (Kazakhstan) standard. The methodic of testing piles by these standards have some differences as long as Kazakhstan Standard is out of date and has not changed science 1994 whereas ASTM is updating and will update taking latest technology developments, technical methods and provides for the use of more modern equipment. Control equipment, technological features, advantages and disadvantages of aforementioned standards might be important for understanding and elimination of existing differences for harmonization with international standards.
\end{abstract}

Keywords: pile, standard, test, control equipment

\section{Introduction}

Development of high-rise buildings and constructions in complex of hydro-geological condition of some regions of Kazakhstan requires reliable design of foundation, this leads to improvement of the geotechnical Standards. Nowadays many international projects are realized in Kazakhstan, this demands to using international Standard, moreover, for realization unique project is required using leading foreign high-tech, economic, ecological and energy-efficient technology, including technology for pile installation, equipment for geological investigation, as well as laboratory testing. Unfortunately, present Standards are confined application of modern technology of pile foundation installation, indicating incomplete usage of advanced technology. So necessities are occurred for scientific reasoning and using of traditional and international Norms give or take geotechnical situations. The results of research will directed to modernization of the Kazakhstan Standards and oriented to advanced geotechnologies adaptation (Tulebekova \& Zhusupbekov, 2011).

\section{Dynamic and Static Load Test Regarding GOST 5686-94 (Kazakhstan)}

Dynamic tests of piles taken regarding requirement GOST 5686-94 «Soils. Field test methods by piles » (Kazakhstan). Test of driven piles by dynamic load include: at the pile driving-counting of the number of jack on each meter sinking and the total number of impact, and on last meter for each $10 \mathrm{~cm}$ sinking; determination of failure of pile after "rest". Write on label through each meter and on last meter through $10 \mathrm{~cm}$ preliminary before sinking. Duration of "rest" fixed by program of test regarding structure, condition soils as follows: day for sandy ground except water saturation; day for clay and heterogeneous soils. The height of the fall of the hammer should be the same for all strikes. For the most current average take rejection pile. Testing results registered in journal, and the test results presented in the form of graphs change which show depending on the depth and the total number of impacts on the depth of the pile driving.

Static tests of piles considered regarding requirement GOST 5686-94 «Soils. Field test methods by piles» (Kazakhstan). Configuration for static pile test shown in Figure 1.

So configuration for static pile test must include as follows: device for loading of pile (jack); bench system for feeling of reaction force (system beam with deadmans); device for determination of displacement piles in test (bench system with gage). Device for loading pile must provided coaxiality and central transference of loading for pile, capacity of transference of loading in discrete steps, constant pressure on each step of loading (Ashkey, 2008).

Displacement axial of testing pile must to be at least $3 \mathrm{~d}$ but more 1,5 $\mathrm{m}$ till deadman. Device for determination 
of displacement of piles (deflectometers) must provide measurement inaccuracy not more $0,1 \mathrm{~mm}$. Quantity of devices must to be at least two which to adjusted symmetric at equal distance (not more $2 \mathrm{~m}$ ) from testing pile (Seidmarova, 2009).

Displacement of piles determined as arithmetic mean value of all devices. Steel wire of diameter $0.3 \mathrm{~mm}$ used on measurement by deflectometers. Of the beginning of measurement steel wire must be pilot strain on 2 days by load $4 \mathrm{~kg}$. In the testing load on the wire must be 1-1.5 kg (Ashkey \& Bazilov, 2010).

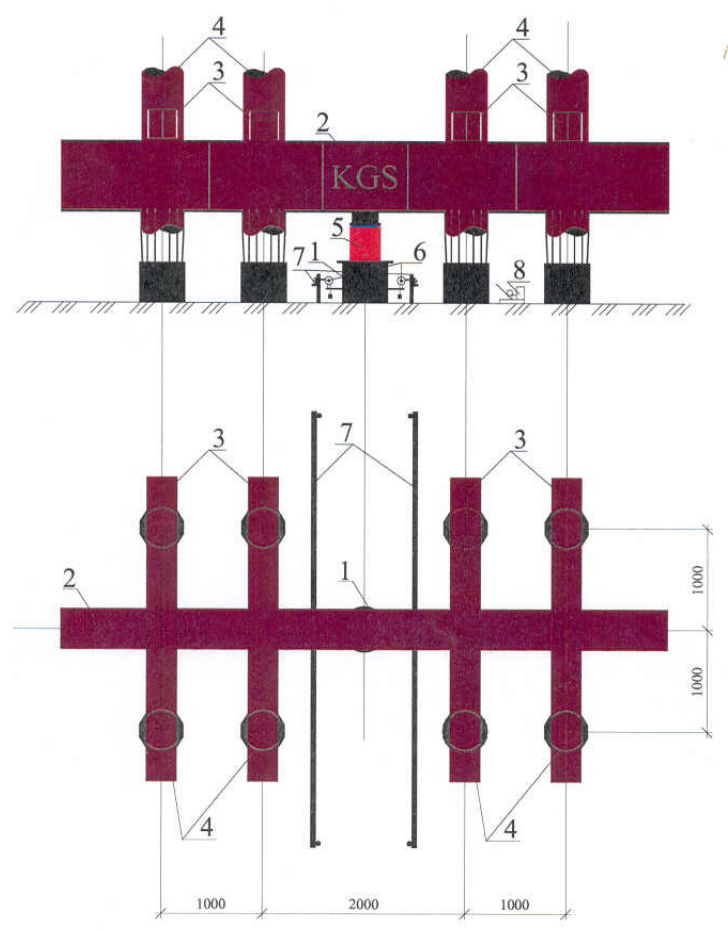

Figure 1. Theme of cable anchorage stand for static tests

1-pile for test, 2-flange beam № 70, 3-secondary beam № 40, 4- anchoring tubing, 5-jack SMJ-158A (capacity 200 ton), 6- deflectometer, 7- bench system, 8- hand reared pumping station HCP-40 with manometer

Measurement range and scale factor of pressure gauge which used for determination load for pile selected relation from maximum load for pile in pile testing. Loading of pile tested even load, without blow value of load installed by program of testing and equal not more $1 / 10$ from maximum load on pile. The first three stages equaled 1/5 from maximum load on pile (Tulebekova \& Turashev, 2011). Reading from all devices determined for all stage of loading pile for measurement of deformation as follows:

- zero reading- before of loading of pile;

- first reading- after that loading;

- then serial four reading with 30 min of interval;

- then through horally till stabilization of deformation.

The criteria of stabilization of deformation in testing are velocity of pile settlement on loading than value not more $0.1 \mathrm{~mm}$ for last as follows:

- $60 \mathrm{~min}$ if occurred sandy soil, clay from dry slag till flexible consistent;

- hours of observation if occurred clay from bumpless consistency till fluidity.

Value of loading must to be which value of settlement of pile at least $40 \mathrm{~mm}$.

The maximum loading not increased of calculating resistance of pile in retesting. Maximum load should not exceed calculation resistance of pile on material at control pile test. Unloading of pile executed after maximum loading step by step Measuring is determined immediately after each step of unloading and after 15 min of observation by devices for measurement deformation. Observations of the elastic displacement of piles should be carried after complete unloading during 30 minutes with sandy soils, 60 minutes for clay soils. Test registered 
and results of pile test formed of graphs which showed dependence settlement of pile from load.Through requirements of СНиП РК 5.01-03-2002 “Свайные фундаменты” load involving settlement of the tested pile, which equals $\mathrm{S}$ and determined according to the below formulae shall be taken as the particular value of the pile ultimate resistance to the pressing load calculated, where coefficient for conversion factor of the limit value of mean settlement of foundation of the building or structure Su,mt into pile settlement obtained while static tests at conventional settlement stabilization; according to the requirements $\zeta=0.2$ shall be taken as the coefficient value.

\section{Static Load Test on Construction Site in Astana According ASTM}

Construction site located at South-East part of capital of Republic Kazakhstan. Territory of Astana city arranged in Kazakh shield so territory isn't seismicity. Construction site located at South-East part of capital of Republic Kazakhstan (Zhusupbekov \& Hoe Ling, 2012). Territory of Astana city arranged in Kazakh shield so territory isn't seismicity Loam, clay, eluvial formation presented by loam with inclusion of gruss and ballast stone, sandstone, siltstone. Geology-lithologic cut of construction shown in Figure 2. Groundwater of construction investigation dissected by all bore hole in depth 1.2-2.3 m, absolute note of sustained level is $349,40 \div 347,70 \mathrm{~m}$.

Permeability coefficient for precipitation as follows: for alluvial loam and clay $-0,53 \mathrm{~m} /$ day; for gravel soil$55,5 \mathrm{~m} /$ day; for eluvial loam- $0,0094 \mathrm{~m} /$ day; for crashed stone- $0,21-1,66 \mathrm{~m} /$ day.

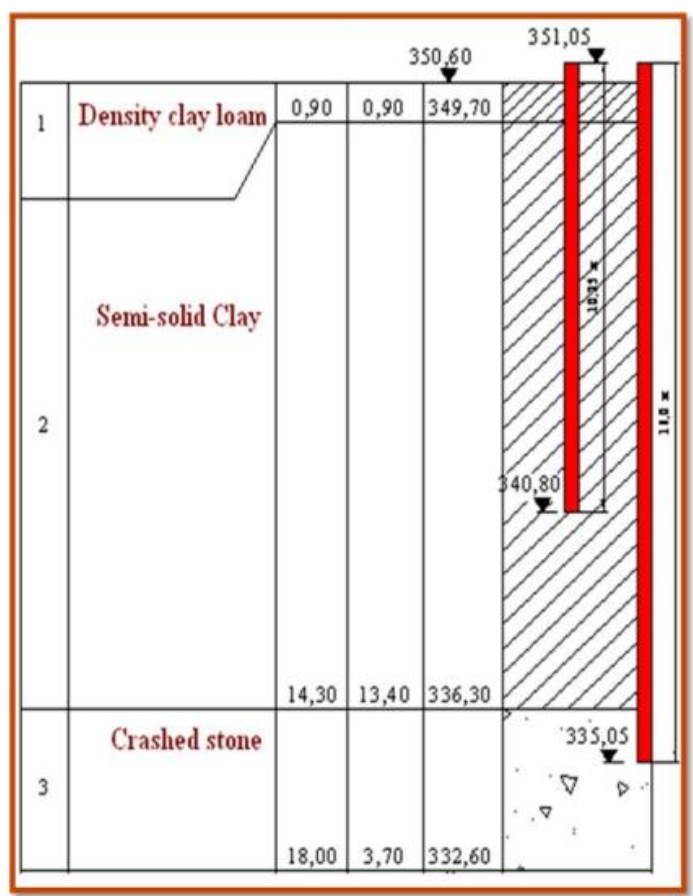

Figure 2. Geology of construction site

A static pile test of steel H-piles was carried out after the "rest" of pile after driving. Results of static test of steel piles before heightening of pile length shown in Table1 and Figure 3 (Базилов, 2008).

Table 1. Results of static test

\begin{tabular}{|c|c|c|c|c|c|c|c|c|}
\hline 品 & 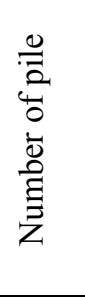 & 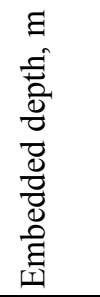 & 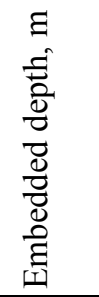 & 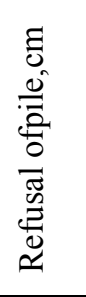 & 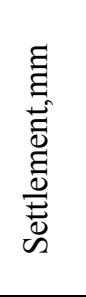 & 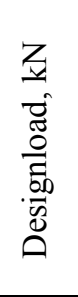 & 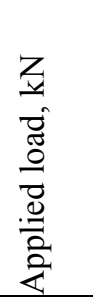 & 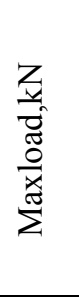 \\
\hline 1 & LT-1 & 7,00 & 9,75 & 0,31 & 4,80 & 600 & 1200 & 1200 \\
\hline 2 & LT-2 & 9,00 & 15,00 & 0,26 & 7,34 & 600 & 1200 & 1200 \\
\hline 3 & LT-3 & 10,00 & 13,00 & 0,32 & 7,00 & 600 & 1200 & 1200 \\
\hline
\end{tabular}




\begin{tabular}{lcccccccc}
4 & LT-4 & 9,25 & 12,75 & 0,27 & 4,96 & 600 & 1200 & 1200 \\
5 & LT-5 & 8,25 & 11,00 & 0,27 & 4,42 & 600 & 1200 & 1200 \\
6 & LT-6 & 10,25 & 16,00 & 0,30 & 6,27 & 600 & 1200 & 1200 \\
7 & LT-7 & 8,00 & 11,25 & 0,78 & 3,38 & 400 & 800 & 800 \\
8 & LT-8 & 8,25 & 11,25 & 0,74 & 2,32 & 400 & 800 & 800 \\
9 & LT-9 & 7,75 & 9,75 & 0,63 & 3,17 & 400 & 800 & 800 \\
\hline
\end{tabular}

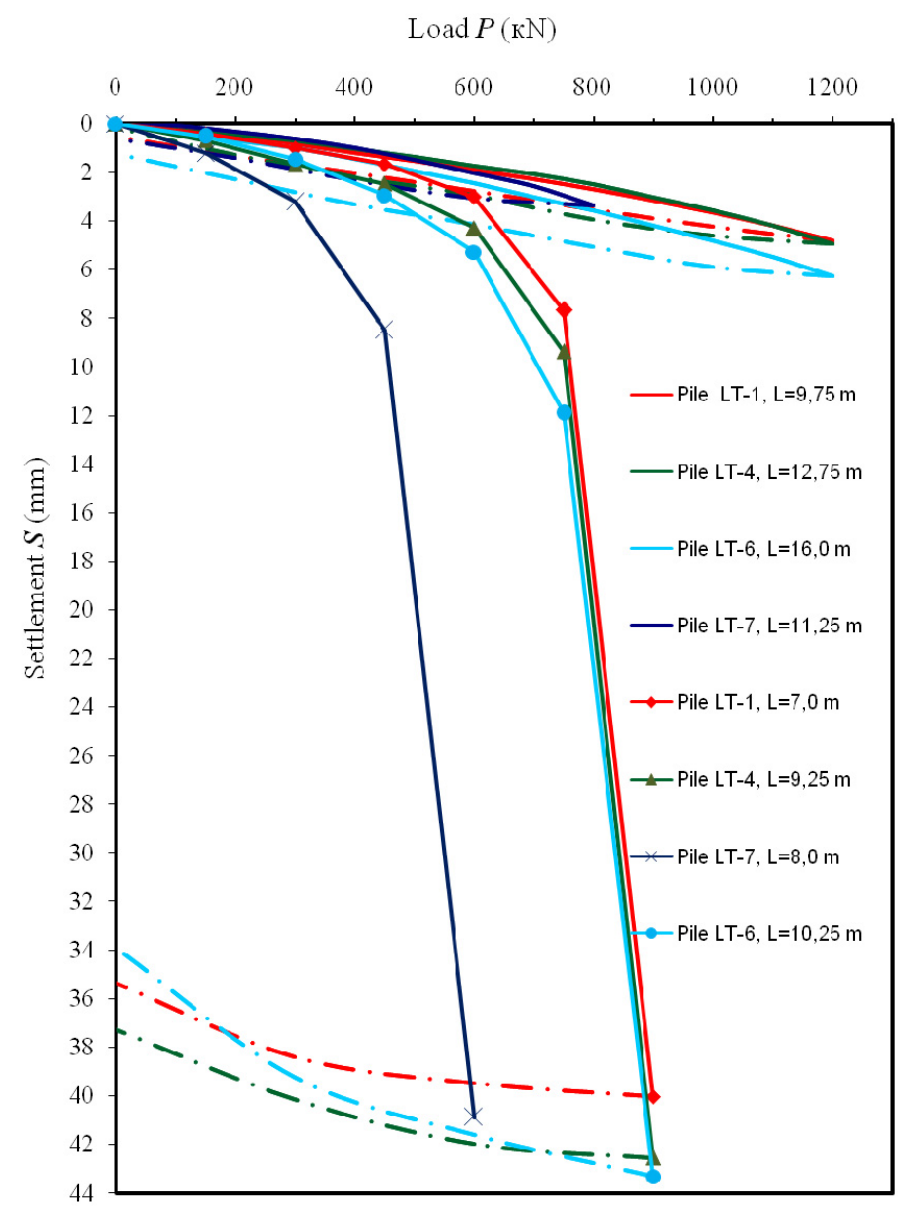

Figure 3. Graphics of dependence of settlement S from load P

\section{Discussion}

Technical specificity of ASTM D1143/D1143M-07 has some differences with national Kazakhstan standard GOST 5686-94. Some devices and control equipment didn't use by requirement of GOST 5686-94 "Soils. Field test". Principal differences between American Standard and Kazakhstan norms showed in Table 3.

Table 3. Equipment using for pile test according to American and Kazakhstan standards

\begin{tabular}{|c|c|c|c|}
\hline $\begin{array}{l}\text { Devices and } \\
\text { equipment }\end{array}$ & GOST & ASTM & Advantages \\
\hline for loading & jack & $\begin{array}{l}\text { jack with } \\
\text { spherical prop }\end{array}$ & \\
\hline \multirow{2}{*}{$\begin{array}{l}\text { Measurement of load } \\
\text { on top pile }\end{array}$} & manometer & manometer & \\
\hline & - & $\begin{array}{l}\text { dynamometer } \\
\text { (more } \\
100 \text { tc) fixed for }\end{array}$ & $\begin{array}{l}\text { allow to control the operation of jacks and } \\
\text { prevent possible non-uniformity of their work, } \\
\text { because that would result in failure of the test }\end{array}$ \\
\hline
\end{tabular}




\begin{tabular}{|c|c|c|c|}
\hline & & each jack & \\
\hline $\begin{array}{l}\text { Measurement of load } \\
\text { on all length pile }\end{array}$ & - & tensometer & \\
\hline $\begin{array}{l}\text { Measurement of axial } \\
\text { displacement of top } \\
\text { pile }\end{array}$ & $\begin{array}{l}\text { transducer of } \\
\text { axial } \\
\text { displacement } \\
\text { of cap }\end{array}$ & $\begin{array}{l}\text { transducer of axial } \\
\text { displacement of } \\
\text { cap }\end{array}$ & $\begin{array}{l}\text { allow to track the eccentric loads at shifting the } \\
\text { focus of the load transfer to the axis of the pile } \\
\text { and compensate them by computational } \\
\text { methods. This will avoid incorrect test results }\end{array}$ \\
\hline & - & visual control & \\
\hline & - & $\begin{array}{l}\text { optical } \\
\text { instrumental } \\
\text { control }\end{array}$ & \\
\hline $\begin{array}{l}\text { Measurement of sway } \\
\text { top pile }\end{array}$ & - & $\begin{array}{l}\text { transducer of } \\
\text { sway top pile }\end{array}$ & $\begin{array}{l}\text { will more accurately determine the draft soil } \\
\text { under the edge of the pile, and the presence of } \\
\text { voids in the pile to separate the real from the } \\
\text { soil sediment compression defective piles }\end{array}$ \\
\hline
\end{tabular}

In practice requirements by American Standard showed that results of test more safety. Because use many control equipment and devices for determination, measurement reverberated. By requirements of both standards on loading pile transferred by jack. But GOST does not consider that each jack need to provide by manometer if we used more than one jack. It's important for control of work of jack and to do correct test (Жусупбеков \& Тулебекова, 2011).

Sometimes ASTM provided fit of reformer of axed displacement of pile bottom relational of it top. Tensometer used for receiving data of pile load (Beim \& Gravare, 1998).

For load above $1000 \mathrm{kN}$ must be used dynamometer for measure the force. Measurement accuracy should not be below $0.01 \mathrm{P}_{\max }$. Dynamometer allows to compensate for possible errors in the hydraulic system and promptly remove it. Also safety increase consequence testing accuracy because have additional system of determination load. Transducer of axled displacement installed on the top of pile of the requirements for the measurement accuracy are same regarding GOST and ASTM (Смолин, \& Захаров, 2010).

ASTM recommended indicator of displacement but GOST recommended indicators, deflectometers with registration of the results of measurements on devices for automatic recording of deformation. However as opposed to GOST, ASTM provided reserve system of axial displacement batter level, laser level meter and steel wire attached of top of pile. Use of the reserve system makes measurements more reliable because the main system insured in case of failure of this system (Smolin, 2010).

In some cases transmitters of axial displacement piles can show multidirectional displacements that explain as follows: nonparallel beam and horizontal plane of the pile top; misalignment of jack and pile; lack of support of jack (Тулебекова, 2012).

But GOST 5686-94 doesn't give instructions in this case. ASTM prescribes that need lateral displacement transducer installed before beginning test for following of monitor of eccentric loads when center of load transfer displaced to axis of pile and balanced by calculation methods. This requirement helped exclude incorrect test results or failure. ASTM provides for the installation of two indicators of displacement on the opposite sides of the pile or monitor of scale which attached for pile by theodolite. Envisage accuracy is about $2.5 \mathrm{~mm}$. Also mandatory requirement regarding American standard provided jack with floating support for reducing the radial load on rod.

Axial displacement transducer used for measure displacement bottom of pile. So we get compression of pile and elasticity of the material during unloading. This measurement can more correct determine settlement of ground and if pile have voids measurement help to find real settlement of ground from pressure of unsound pile.

For the purposes, ASTM proposes to use a system of measurement of the indicator displacement, installed on top of the pile.

In case of not axial device installed device of two rods and indicators at the same distance from the axis of the pile oppositely to one another. Pipe is equipped for rods in which they can move freely inside. The pipes are installed in the hole before filling it with concrete. Pipes should rest against the plate fixed to the pile. 
Force transducer to measure the lateral resistance pile used to measure the friction force on his side the entire length of the pile. Thus, we can determine the distribution of the lateral resistance of piles. GOST requires that need static load tested for determination integral characteristics of lateral resistance of pile.

However, these tests are cumbersome and uneconomical compared with the transmitters according to ASTM.

\section{Conclusion}

Since 1994 year Kazakhstan Standard has not changed, ASTM standard was updated in 2007, and therefore takes latest developments in technology and technical terms and provides for the use of more modern equipment (Мангушев \& Ершов, 2007).

The analysis in the article shows that the tests with ASTM makes them more reliable and gives detailed information about the process of testing and the results.

Actual question today is to update the national standards, harmonization with international standards. The introduction of innovations described will avoid making wrong results of test. Along with TC55 work Design Academy "KAZGOR" (Kazakhstan) conducts research on the existing international experience of echnical regulations to ensure the safe construction processes and products And members of these Committees registered that in practice tester sometimes has situations when make wrong design because in normative isn't detailed information.

ASTM showed new improvement in pile tests. Method of pile testing regarding Kazakhstan Standard comparison with American Standard it is becomes obvious disadvantage.

Unfortunately, present Kazakhstan Standard are confined application of modern pile technology and big difference between experimental bearing capacity obtained by static loading test (SLT) and design value obtained by Kazakhstan Standard indicated incomplete usage of modern pile technology technology. And so research of advanced pile technologies $\mathrm{w}$ is very important for the feature Kazakhstan geotechnic development (Тулебекова \& Султанов, 2010).

\section{References}

Ashkey, E. (2008). Interactions of CFA bored piles with soil conditions in Astana (Doctoral dissertation, L N Gumilyov Eurasian National University, Kazakhstan).

Ashkey, Y., Bazilov, R. K., \& Tulebekova, A. S. (2010). The application of dynamic and static piling tests of Kazakhstan. Proceedings of the Kazakhstan-Korean Geotechnical Seminar. Geotechnical Infrastructure in Megacities and New capitals, 91-97.

ASTM D1143/D1143M-07. Standard. Test Methods for Deep Foundations Under Static Axial Compressive Load., ASTM International.

Beim, J., Gravare, C. J., Klingmuller, L. De-Quing, \& Rausche, F. (1998). Standartization and Codification of Dynamic and Static Pile Testing, a Worldwide Review // Deep Foundations Institute.

Fleming, W. G. K., Weltman, A. J., Randolph, M. F., \& Elson, W. K. (1992). Piling Engineering (2nd ed.). UK, Glasgow: Blackie Academic \& Professional, p. 390.

GOST 5686-1994. Soils. Field test methods be piles. M.: Standards Publishing House.

MSP 5/01-101-2003-Design and installationofpile foundation

Poulos, H. G., \& Davis, E. H. (1980). Pile foundation analysis and design // Series in geotechnical engineering. John Wiley \& Sons, p. 397.

Seidmarova, T. Zh. (2009). Bearing capacity evaluation by results of static and dynamic load tests. (Doctoral dissertation, L N Gumilyov Eurasian National University, Kazakhstan).

Smolin, B. S. (2010). Features pile load test by ASTM. Proc. intern. symp. Russia.

SNiP RK 5.01-01-2002 "Soil basement and foundations".

SNIP RK 5.01-03-2002-Pile Foundation, Astana, KAZGOR, 2003.

Tulebekova, A. S., Turashev, A. S., Muzdybayeva, T., \& Uzak, E. T. (2011). Analysis of the interaction between construction and soil ground under influence of the static load. 14th Asian Regional Conference on Soil Mechanics and Geotechnical Engineering, p. 44.

Tulebekova, A. S., Zhusupbekov, A. Zh., \& Lukpanov, R. (2011). Geotechnical construction of piling foundations on problematical soil ground of Kazakhstan. Proceedings of Indian geotechnical Conference, 
$7-15$.

Urkkada Technology (1998). Report to Loadtest Inc. on the analysis of a-cell test at the My Thuan Bridge Project, Vietnam.

Van Impe, W. F. (1991). Developments in pile design. DFI Conference. Stresa, p. 32.

Van Impe, W. F. (1997). Pile foundations design. XVI Conference of Geotechnics. Torino, p. 36.

Zhusupbekov, A. Zh., \& Ashkey, Y. (2007). Geotechnical Problems of Mega Projects on Difficult Soil Ground in Kazakhstan. Proceedings International Symposium, pp. 28-40

Zhusupbekov, A. Zh., Hoe Ling, Lukpanov, R., Tulebekova, A. S., Yenkebayev, S., \& Sultanov, G. A. (2012) Geotechnical issues of piling foundations on problematical soil ground of Kazakhstan.

\section{Copyrights}

Copyright for this article is retained by the author(s), with first publication rights granted to the journal.

This is an open-access article distributed under the terms and conditions of the Creative Commons Attribution license (http://creativecommons.org/licenses/by/3.0/). 